Foreign shareholding: A decomposition analysis

Ajay Shah and Ila Patnaik

Working Paper 2010-74

October 2010

NIPFP-DEA Research Program

National Institute of Public Finance and Policy

New Delhi

http://macrofinance.nipfp.org.in 


\title{
Foreign shareholding: A decomposition analysis
}

\author{
Ajay Shah Ila Patnaik
}

November 3, 2010

\begin{abstract}
Stulz (2005) has emphasised that for home bias to decline, insiders have to reduce ownership so as to make purchase of shares by foreigners possible. We offer a decomposition in the ownership of shares by foreigners into three parts: the change in insider shareholding, the change in market capitalisation and the change in the fraction of outside shareholding that is held by foreigners. As an example, this decomposition is applied to help understand the sharp change in foreign ownership of Indian firms after 2001.
\end{abstract}

JEL Codes: G1, G15.

Keywords: Home bias; foreign investors. 


\section{Introduction}

Three classes of explanations play a role in explaining the change in the dollar value of shares of a country that are held by foreigners. Changes in the market capitalisation could induce a bigger dollar value of foreign ownership, if foreign investors preserve erstwhile levels of home bias. Changes in insider shareholding could modify the space available for foreign investors (Stulz, 2005), which we term the 'Stulz effect'. Finally, the fraction of outside shareholding held by foreigners could change.

In this paper, we offer a decomposition of changes in the value of foreign ownership. This gives a simple accounting framework to assess the relative importance of these three effects.

As an illustration, we apply these ideas to analysing the evolution of foreign share ownership in India. India opened up to foreign portfolio investment in 1993. In March 2003, the market value of shares owned by all foreign investors stood at $\$ 11.5$ billion. In March 2007, the market value of shares owned by foreign investors had risen to $\$ 151.3$ billion. Our decomposition offers useful insights into this increase in the value of foreign ownership of Indian equities of 13 times in 4 years. We find that the bulk of the change was caused by larger market capitalisation of Indian equities, and by a bigger fraction of outside shareholding being purchased by foreigners. The 'Stulz effect' did not play a substantial role.

\section{The decomposition}

When analysing the dollar value of shares owned by foreign investors, three sources of change can be identified:

- Change in market capitalisation

The simplest source of change in the value of shares owned by foreigners lies in the change in the market capitalisation. An ICAPM portfolio would hold more shares of a country when the market capitalisation is higher.

- Change in insider ownership

Stulz (2005) has emphasised that insider ownership limits the extent to which foreign shareholding can increase. As an example, the ICAPM weight of India in the world portfolio is $1.5 \%$. In this case, foreigners 
should own $97.5 \%$ of Indian firms. However, if insiders find it optimal to hold substantial stakes in the firms that they control, then the elimination of home bias is mechanically infeasible. Stulz argues that the elimination of home bias is hence infeasible until the institutional environment of a country enables a shift towards dispersed ownership.$^{1}$

\section{- Change in fraction of outside shareholding owned by foreigners}

The third aspect lies in changes in the fraction of outside shareholding that is in the hands of foreigners. Traditional sources of home bias include firm characteristics such as liquidity, information and accounting standards of the firm.

In order to obtain a quantitative sense of the role played by these three aspects of the problem, we obtain a decomposition of $F$, the value of foreign ownership of shares in an emerging market. Let

$$
F=g(1-p) M
$$

where $M$ is the market capitalisation of the country; $p$ is the insider shareholding and $g$ is the fraction of outsider shareholding that is held by foreigners. Total differentiation yields:

$$
\Delta F \approx M(1-p) \Delta g+g(1-p) \Delta M-g M \Delta p
$$

The first term, $M(1-p) \Delta g$, can be interpreted as the change in $F$ associated with a change in $g$ holding other things constant. This corresponds to traditional home bias explanations.

The second term, $g(1-p) \Delta M$, measures the rise in foreign ownership owing to a higher $M$, holding other sources of home bias unchanged. It reflects foreign investors preserving their ownership of $g(1-p)$ on a larger $M$, reflecting ICAPM-style reasoning while ignoring changes in world market capitalisation.

The third term, $-g M \Delta p$, may be termed a 'Stulz effect', reflecting the drop in foreign ownership associated with a rise in insider ownership $p$, while holding other things constant.

${ }^{1}$ Kho, Stulz, and Warnock $(2006)$ examine the empirical evidence from two points of view. First, using aggregate data, they find that the home bias of US investors declined the most from 1994 to 2004 for countries which (a) had lower insider shareholding in 1994 and (b) had a decline in insider shareholding from 1994 to 2004. Further, using firm-level data for Korea, they document how a sharp reduction in home bias was critically enabled by a class of firms where the insider shareholding declined sharply. 


\begin{tabular}{|c|c|c|c|}
\hline \multirow[t]{2}{*}{ Parameter } & March 2001 & March 2007 & \multirow{2}{*}{$\begin{array}{r}\text { Rise } \\
\text { (times) }\end{array}$} \\
\hline & \multicolumn{2}{|c|}{ (Billion dollars) } & \\
\hline CMIE COSPI market capitalisation & 114.1 & 803.1 & 7.04 \\
\hline Foreign ownership & 10.9 & 151.3 & 13.9 \\
\hline \multicolumn{4}{|c|}{ Table 2 Change in home bias against India } \\
\hline & March 2001 & March 2007 & \\
\hline ICAPM weight of India & 0.42 & 1.53 & \\
\hline Actual weight of India & 0.04 & 0.24 & \\
\hline Home bias metrics & & & \\
\hline 1 - (actual/ICAPM) & 0.92 & 0.82 & \\
\hline ICAPM /actual & 10.38 & 5.42 & \\
\hline
\end{tabular}

This decomposition is not an economic model explaining the dynamics of $F$. Rather, it represents an attempt at accounting for the changes in $F$ and obtaining a quantitative sense of the importance of the three forces at work.

\section{An example}

Our data for Indian firms is drawn from 'Prowess', a firm-level database for Indian firms from the Centre for Monitoring the Indian Economy. The set of firms that we focus on is members of the CMIE COSPI stock market index. This is defined as all listed firms where trading takes place on atleast twothirds of the days in the last six months. We focus on data for 31 March of each year, which is the end of the financial year.

We focus on the period after 2001, a period in which there was stability of capital controls and of the institutional features of the equity market. As Table 1 shows, over the six-year period under examination, dramatic changes took place in foreign ownership of Indian equities. While the Indian equity market capitalisation went up by 7.04 times, the market value of foreign ownership went up by 13.9 times.

Table 2 interprets these changes from a home bias perspective. The share of Indian equity market capitalisation in world equity market capitalisation went up from $0.42 \%$ to $1.53 \%$ over this period. The actual ownership of Indian equities by foreigners went up from $0.04 \%$ to $0.24 \%$ of the world 


\begin{tabular}{crrrr}
\hline Table 3 Shareholding pattern of Indian firms & \\
\hline Year & $\begin{array}{r}\text { For. own. } \\
\text { (fraction of } \\
\text { outsider) }\end{array}$ & $\begin{array}{r}\text { Insider own. } \\
\text { (fraction of } \\
\text { total) }\end{array}$ & $\begin{array}{r}\text { Market capn. } \\
\text { (Trn. Rs.) }\end{array}$ & $\begin{array}{r}\text { Foreign market capn. } \\
\text { (Trn. Rs.) }\end{array}$ \\
\hline 2001 & 0.2049 & 0.4804 & 4.80 & 0.51 \\
2002 & 0.2271 & 0.5122 & 5.50 & 0.61 \\
2003 & 0.2105 & 0.5161 & 5.37 & 0.55 \\
2004 & 0.2798 & 0.5354 & 11.51 & 1.49 \\
2005 & 0.3091 & 0.5555 & 16.63 & 2.28 \\
2006 & 0.3349 & 0.5323 & 29.69 & 6.65 \\
2007 & 0.4100 & 0.5471 & 35.13 & 6.52 \\
\hline
\end{tabular}

portfolio. While the normative share of India in the world portfolio went up by 3.64 times, the actual share of India went up by 6.97 times. As a consequence, home bias against India declined. The ICAPM weight went from being 10.38 times bigger than the actual in March 2001, to being 5.42 times bigger in March 2007.

Table 3 summarises facts about our dataset. From March 2001 to March 2007, the overall market capitalisation of Indian firms went up from Rs.4.8 trillion to Rs.35.13 trillion. The value of foreign ownership went up from Rs.0.51 trillion to Rs.6.52 trillion. Foreign ownership rose sharply from $21.05 \%$ of the outside shareholding (worth Rs.0.55 trillion) in 2003 to $41 \%$ of outside shareholding (worth Rs.6.52 trillion) in 2007.

We find that from 2001 till 2007, the insider ownership went up from 48.04\% to $54.71 \%$. The 'Stulz effect' was playing against foreign shareholding. ${ }^{2}$ At the same time, the fraction of outside shareholding owned by foreigners went up significantly, from $20.49 \%$ to $41.0 \%$.

Table 4 applies the decomposition of $\Delta F$ in equation 2 to interpreting the Indian experience. Because $g, p$ and $M$ undergo large changes, the calculusbased formula is only an approximation. In the table, the three components are shown, as is the discrepancy against the observed $\Delta F$. In 2004 , the discrepancy is $11 \%$ of $\Delta F$, but apart from that, it attains small values.

As an example, in 2007, $F$ rose by Rs.1872 billion. We decompose this change into three elements. It reflects a decline of Rs.213 billion owing to the Stulz effect, for insider shareholding went up in 2007. There was a rise of Rs.1011

\footnotetext{
${ }^{2}$ A decomposition by size (i.e. market capitalisation) shows that insider shareholding went up in all size deciles between 2001 and 2007, except for a slight decline in the bottom, 8th and 9th deciles.
} 


\begin{tabular}{|c|c|c|c|c|c|}
\hline & & & & \multicolumn{2}{|c|}{ (Billion rupees) } \\
\hline & \multicolumn{3}{|c|}{ Components } & \multirow[b]{2}{*}{ Discrepancy } & \multirow[b]{2}{*}{$\Delta F$} \\
\hline Year & Traditional & ICAPM & Stulz & & \\
\hline 2002 & 59 & 77 & -40 & -1 & 97 \\
\hline 2003 & -43 & -13 & -4 & 1 & -62 \\
\hline 2004 & 371 & 799 & -62 & 158 & 950 \\
\hline 2005 & 217 & 703 & -104 & 28 & 788 \\
\hline 2006 & 358 & 2046 & 231 & 269 & 2366 \\
\hline 2007 & 1193 & 1011 & -213 & 119 & 1872 \\
\hline
\end{tabular}

billion owing to the rise in the market capitalisation of the Indian equity market. Finally, there was a rise of Rs.1193 billion owing to an increase in the fraction of outside shareholding held by foreigners. Re-expressing the components as percent of $\Delta F$, the contributions were: $+64 \%$ owing to traditional home bias explanations; $+54 \%$ owing to ICAPM explanations and $-11 \%$ owing to the Stulz effect.

\section{Conclusion}

This paper offers a decomposition of changes in the dollar value of shares held by foreigners in a country. This constitutes an accounting framework for assessing the relative importance of three factors: increase in market capitalisation, decline in insider ownership and traditional explanations of home bias. As an example, we use this approach to analyse the episode in India, where the dollar value of shares owned by foreigners went up by 13.9 times over a six year period. We find that the 'Stulz Effect' did not play a role in this evolution. Roughly half of the change was owing to increased market capitalisation in India, and the remaining half reflected the increase in outside shareholding held by foreigners.

\section{References}

Kho, B.-C., R. M. Stulz, and F. E. Warnock (2006): "Financial globalisation, governance and the evolution of the home bias," Discussion Paper 220, BIS. 
Stulz, R. M. (2005): "The limits of financial globalisation," Journal of Finance, LX(4), 1595-1638. 